\title{
Cytotoxic Activity of Antineoplastic Agents on Fertility: A Systematic Review
}

\section{Atividade citotóxica dos tratamentos antineoplásicos na fertilidade: Uma revisão sistemática}

\author{
Gabriel Acácio de Moura10 Paula Bruno Monteiro ${ }^{210}$ \\ 1 Universidade Estadual do Ceará, Fortaleza, CE, Brazil \\ ${ }^{2}$ Centro Universitário Christus Unichristus, Fortaleza, CE, Brazil \\ Address for correspondence Gabriel Acácio de Moura, Av. Dr. Silas \\ Munguba, 1700 60714-903, Fortaleza, CE, Brazil (e-mail: \\ gabrielacacio.ed@gmail.com).
}

Rev Bras Ginecol Obstet 2020;42(11):759-768.

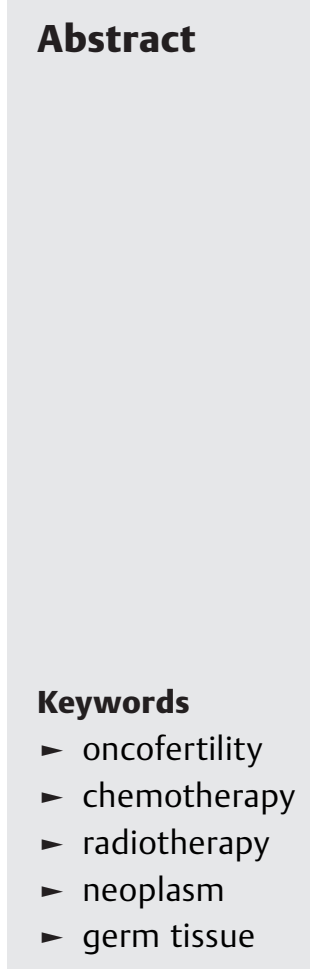

Resumo
Objective To analyze the long-term effects of antineoplastic treatments on patient fertility.

Selection of Studies The studies were selected through the New PubMed, Scielo and Lilacs databases along with references used for the creation of the present work. For the selection of studies, articles published between the periods from January 1, 2015 to April 6, 2020 in the English, Portuguese and Spanish languages were used. As inclusion criteria: cohort studies and studies conducted in vitro. As exclusion criteria: review articles, reported cases, studies that do not address thematic reproduction, studies that do not address the cancer theme, articles that used animals, articles that address the preservation of fertility and articles in duplicate in the bases.

Data Collection The collected data included: age of the patient at the beginning of treatment, type of neoplasm, type of antineoplastic treatment, chemotherapy used, radiotherapy dosage, radiotherapy site, effect of antineoplastic agents on fertility and number of patients in the study.

Data Synthesis Thirty studies were evaluated, antineoplastic chemotherapy agents and radiotherapy modulate serum hormone levels, reduces germ cell quantities and correlated with an increase in sterility rates. The effects mentioned occur in patients in the prepubertal and postpubertal age.

Conclusion Antineoplastic treatments have cytotoxic effects on the germ cells leading to hormonal modulation, and pubertal status does not interfere with the cytotoxic action of therapies.

Objetivo Analisar os efeitos a longo prazo dos tratamentos antineoplásicos na fertilidade de pacientes.

Fontes de dados Os estudos foram selecionados através das bases de dados New PubMed, Scielo e Lilacs, junto com as referências utilizadas para a confecção do trabalho.

Seleção dos estudos Para a seleção dos estudos, foram utilizados artigos publicados entre os períodos de 01 de janeiro de 2015 a 06 de abril de 2020 nos idiomas inglês, received

November 28, 2019

accepted

May 21,2020
DOI https://doi.org/

10.1055/s-0040-1713911. ISSN 0100-7203.
Copyright $(2020$ by Thieme Revinter

Publicações Ltda, Rio de Janeiro, Brazil
License terms

(c) (9) 


\section{Palavras-chave \\ - oncofertilidade \\ - quimioterapia \\ - radioterapia \\ - neoplasia \\ - tecidos germinativos}

\begin{abstract}
português e espanhol. Como critérios de inclusão: estudos de coorte e estudos realizados in vitro. Como critérios de exclusão: artigos de revisão, relatos de caso, estudos que não abordavam a temática reprodução, estudos que não abordavam a temática câncer, artigos utilizando animais, artigos que abordavam preservação da fertilidade e artigos em duplicidade nas bases.

Coleta de dados Os dados coletados incluíram: idade do paciente ao início do tratamento, tipo de neoplasia, tipo de tratamento antineoplásico, quimioterápicos utilizados, dosagem da radioterapia, local da radioterapia, efeito dos agentes antineoplásicos na fertilidade e número de pacientes dentro do estudo.

Síntese de dados Trinta estudos foram avaliados. Os agentes quimioterápicos antineoplásicos e a radioterapia modulam níveis séricos hormonais de marcadores de fertilidade, reduzem a quantidade de células germinativas e estão correlacionados com um aumento da taxa de esterilidade. Os efeitos citados anteriormente ocorreram em pacientes com idade pré-púbere e pós-púbere.

Conclusão Os tratamentos antineoplásicos possuem efeitos citotóxicos em células germinativas, levando a modulação hormonal, e o status puberal não interfere diretamente na ação citotóxica das terapias.
\end{abstract}

\section{Introduction}

Cancer (CA) is defined as a heterogeneous syndrome that evolves in several ways, this change being the result of a mutation in the activity of multiple oncogenes and tumor suppressor genes. ${ }^{1}$ In this pathology, we can find much more than the proliferation of cancerous cell masses as well as the formation of complex cell phenotypes and distinct cell compounds participating in heterotypic interactions with each other. $^{2}$ According to the World Health Organization (WHO) in $2018,{ }^{3}$ CA was considered the main cause of death in the world, registering $\sim 9,6$ million notifications.

The monitoring of the personal history of patients with CA is an object of great importance, since the increased risk of neoplasms may be directly associated with epidemiological risk factors such as cigarette use, alcoholism, obesity or genetic factors as predisposition to breast CA by the presence of the BRCA1 gene and translocation of the BCR-ABL gene to leukemias. ${ }^{4}$ Because of this, the frequent rush to develop methodologies that promote improvement in the survival of these patients has made great leaps. ${ }^{5}$

Among the currently available therapeutic modalities, we can mention chemotherapy and radiotherapy, which cause several short-term effects accompanied by more serious adverse effects, such as cardiovascular activities, worsening renal function and nephrotoxicity. ${ }^{6-8}$ In view of the above, therapies that aim to improve the chances of survival of the patient may end up having a significant weight, reducing their quality of life. ${ }^{5}$

Antineoplastic chemotherapy agents (AQAs) are characterized by the use of cytotoxic drugs individually or in combination, to act in different phases of cell division, in cells that present dysfunction in the process of growth or cell division. ${ }^{9}$ However, in the long run, due to the lack of specificity of AQAs, they can attack normal cells that renew themselves in regular periods as germ cells, having an important weight due to the high testicular and ovarian sensitivity to these cytotoxic agents. ${ }^{10}$

Antineoplastic Radiotherapy (AR) consists of the administration of radioactive sources in preconditioned dosages on a body surface that leads to cell apoptosis of the cells in the region. ${ }^{11}$ In women, pelvic radiotherapy in dosages established between 5 and $10 \mathrm{~Gy}$ is already considered toxic due to ovarian radiosensitivity. ${ }^{10}$ In men, small direct doses as in $0.1 \mathrm{~Gy}$ therapy can cause damage to the sperm, leading to a drop in the number of sperms in the ejaculation. ${ }^{12}$

The damage to the germinal organs depends on several factors, including the drugs used during treatment, the radiotherapy dose used, the age of the patient at the time of treatment and the basal state of the tissue, being used for the identification that caused loss of quality in the presence of a biomarker. ${ }^{13}$ Thus, a hormonal dosage ends up becoming a valid alternative for the identification and prediction of the fertility of the patients, since these hormonal adjustments occur through neuroendocrine processes characterized by the activation of the hypothalamic pituitary-axis and release of luteinizing hormone ( $\mathrm{LH})$ and follicle stimulating hormone (FSH), for the development of both sexual male and female gametes, in addition to the presence of other markers such as the anti-mullerian hormone (AMH), estradiol $\left(E_{2}\right)$ and the antral follicles count (AFC), which mark sexual development. ${ }^{14,15}$

Due to the different chronological rhythm of patients in prepubertal status, characterized by low dosages of hormonal release and absence of gamete development, it was believed that this profile of patients undergoing antineoplastic therapies reduced cytotoxic damage to germ cells. ${ }^{16}$ However, studies on rats have shown that with antineoplastic treatment, rats in the prepubertal state have had their reproductive functions reduced or impaired. ${ }^{17-19}$ 
Therefore, the present review aims to analyze, through a systematic review of the literature, the activity of antineoplastic treatments (chemotherapy and radiotherapy) on the fertility of patients undergoing CA treatment.

\section{Methods}

\section{Study Type}

The present study is a systematic literature review in which we outline an objective search methodology to answer the question regarding the proposed theme, using a collection of studies. $^{20}$ The present systematic review was performed according to the Preferred Reporting Items for Systematic Reviews and Meta-Analyses (PRISMA) guide reports (http:// www.prisma-statement.org/PRISMAStatement/). ${ }^{21}$

\section{Study Eligibility Criteria}

1 - Studies: Clinical trials were used for the present review, verifying different toxic effects of chemotherapy and radiotherapy or chemotherapy used alone in fertility; 2 - Publication period: Articles published in the period between January 1, 2015 and April 6, 2020 were considered eligible for analysis;

3 - Language of studies: Studies in English and Spanish were used to make the present work;

4 - Intervention used: Clinical trials involving chemotherapy and radiotherapy or just chemotherapy showing their adverse effects both in vivo and in vitro. Studies that address adverse unit effects of antineoplastic treatments with the aid molecules that would preserve fertility were disagreed studies.

5 - Outcomes: Effects of antineoplastic treatments on post-treatment patient gestational rate, effects of ovarian reserve of female patients through the measurement of hormonal markers such as HMA, $E_{2}$, LH and FSH; the same also applies to the production of sperm in male patients and defects in its morphology, quantity and viability.

\section{Search of Databases}

For the search, the New PubMed, Scielo and Lilacs databases were used, and the search was performed manually. For its realization, a combination of advanced research was used among the descriptors for all databases: (Cancer AND Neoplasm AND Chemotherapy antineoplastic AND fertility AND effect) for chemotherapy. For radiotherapy, the following descriptors were used (Cancer AND Neoplasm AND Radiotherapy antineoplastic AND fertility AND effect).

\section{Selection Criteria for Studies}

\section{Inclusion Criteria}

1 - Cohort studies through clinical trials that analyzed the relationship between antineoplastic treatments and fertility;

2 - In vitro studies using cryopreservation and in vitro maturation of patients with CA.

\section{Exclusion Criteria}

1 - Review articles;

2 - Case reports;

3 - Studies that did not address the theme of reproduction;

4 - Studies that did not address the theme of CA;

5 - Animal studies;

6 - Articles that addressed fertility preservation;

7 - Duplicate articles.

\section{Data Collection}

Initially, a search was performed in the databases using the referring descriptors. Soon after, titles and abstracts of the articles were evaluated based on the aforementioned inclusion and exclusion criteria. Then, after selecting eligible articles for the creation of the present review, they were released for data extraction.

\section{Antineoplastic Chemotherapy}

1 - Age of the patient at the diagnosis of CA;

2 - Type of neoplasm;

3 - Type of treatment (Chemotherapy + Radiotherapy or Chemotherapy alone);

4 - AQAs cited in the study;

5 - Possible AQA activity in fertility;

6 - Number of patients evaluated in the study.

\section{Antineoplastic Radiotherapy}

1 - Age of the patient at the diagnosis of CA;

2 - Type of neoplasm;

3 - Type of treatment (Radiotherapy + Chemotherapy or Radiotherapy alone);

4 - Radiation site;

5 - Possible Antineoplastic Radiotherapy (AR) activity in fertility;

6 - Number of patients evaluated in the study;

7 - Dosage used.

\section{Results}

A total of 401 articles were found, of which 30 articles were selected from the screening in the New PubMed, Scielo and Lilacs databases for the elaboration of the present review, as shown in - Fig. 1.

In the present review, the literature demonstrated different antineoplastic therapies for different types of CA as show in - Table 1 and - Table 2, with the main types of cancer studied being breast CA and Hodgkin Lymphoma. In these studies, the patients included had an age range from 0 to 50 years old.

\section{Antineoplastic Chemotherapy Agents Modulate Serum Hormonal Secretion and Alter Germ Cell Production and Quality in Patients Undergoing Cancer Treatment}

The literature shows us that, in different types of CA, the treatment with AQAs led to a modulation in serum hormonal concentrations. In 11 studies, there was a significant reduction in the hormonal levels of $\mathrm{AMH}, \mathrm{E}_{2}, \mathrm{LH}$, and FSH. ${ }^{22-43}$ In contrast, 8 studies showed an increase in hormone levels during treatment, such as FSH, LH, AMH, and $\mathrm{E}_{2}$. $25-27,30,33,40-42$ 
762 Cytotoxic Activity of Antineoplastic Agents on Fertility Moura, Monteiro
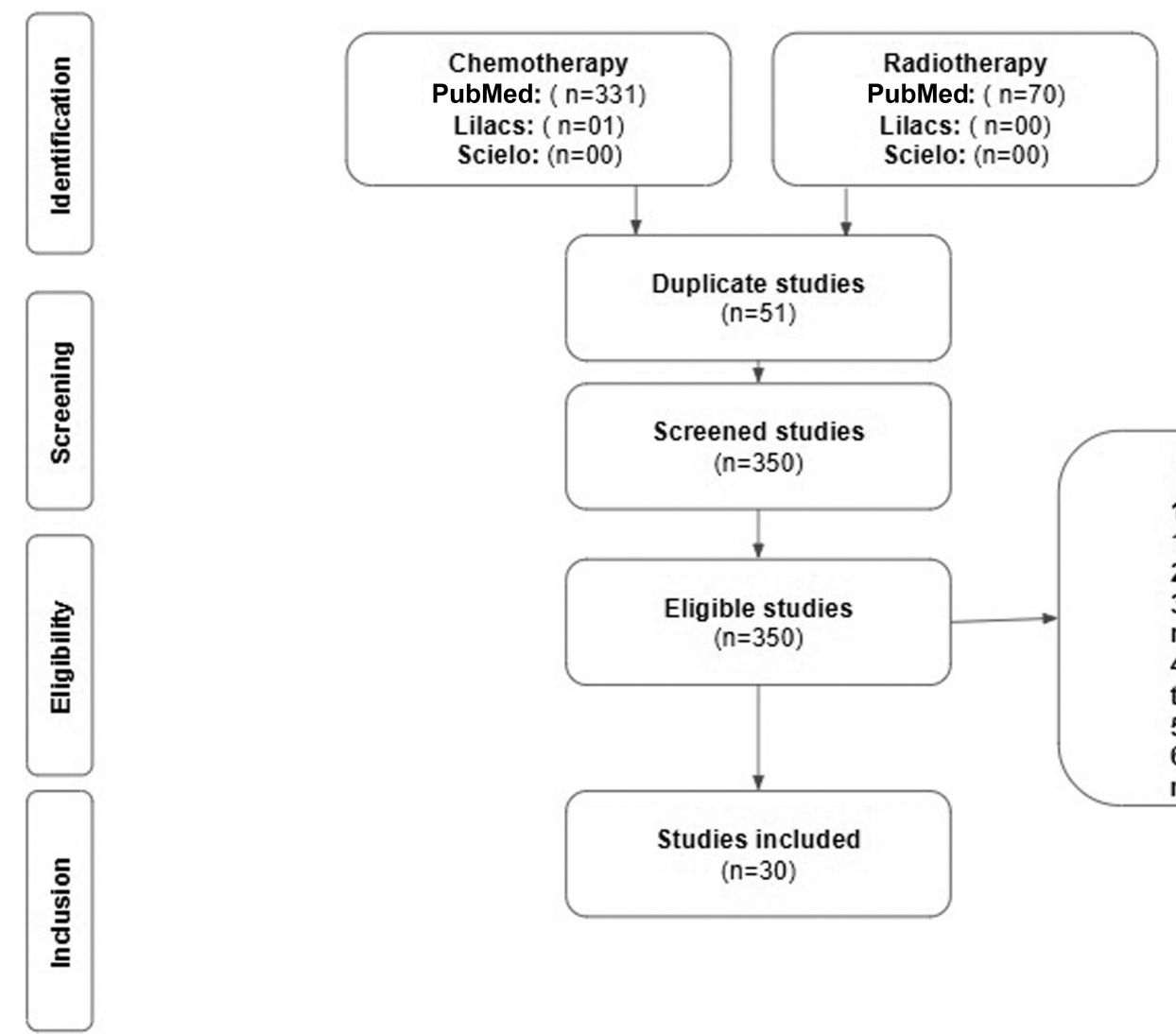

PubMed: $(n=331)$

Lilacs: $(n=01)$

$:(n=00)$

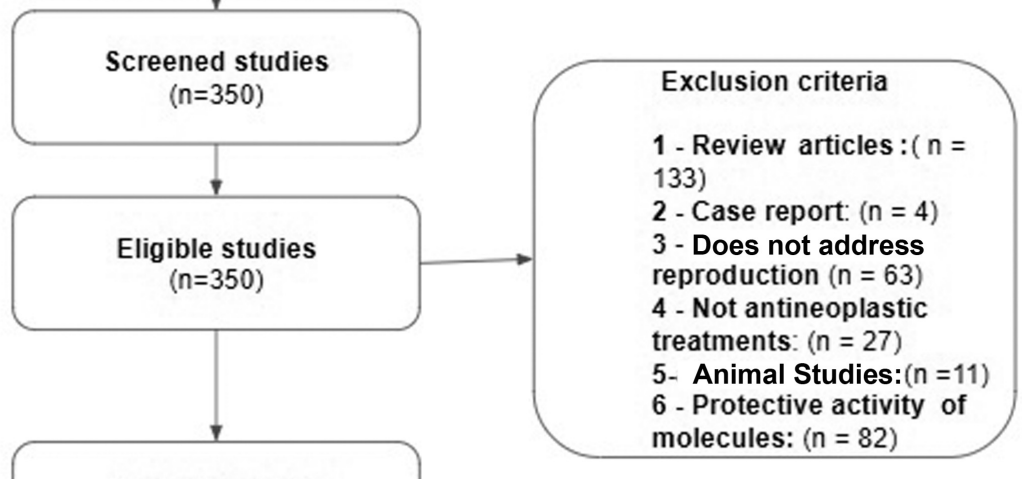

Studies included

$(n=30)$

Fig. 1 Methodological screening.

Table 1 Influence of antineoplastic chemotherapy agents on fertility pattern

\begin{tabular}{|c|c|c|c|c|c|c|}
\hline Author & Age & Tumor type & Treatment & $\begin{array}{l}\text { Antineoplastic } \\
\text { agent }\end{array}$ & Effect & $\begin{array}{l}\text { Number } \\
\text { of patients }\end{array}$ \\
\hline Gini et al $(2019)^{22}$ & $16-50$ years old & $\begin{array}{l}\text { Hodgkin Lymphoma } \\
\text { Non-Hodgkin } \\
\text { Lymphoma }\end{array}$ & $\begin{array}{l}\text { Chemotherapy } \\
+ \\
\text { Radiotherapy }\end{array}$ & $\begin{array}{l}\text { Etoposide } \\
\text { Doxorubicin } \\
\text { Cyclophosphamide } \\
\text { Vincristine } \\
\text { Prednisone } \\
\text { Bleomycin }\end{array}$ & $\uparrow$ Amenorrhea & 97 \\
\hline $\begin{array}{l}\text { Shandley et al } \\
(2018)^{23}\end{array}$ & 20-35 years old & $\begin{array}{l}\text { Breast Cancer } \\
\text { Lymphomas } \\
\text { Reproductive Tumor }\end{array}$ & Chemotherapy & - & $\begin{array}{l}\downarrow \mathrm{AFC} \\
\downarrow \mathrm{AMH}\end{array}$ & 1090 \\
\hline $\begin{array}{l}\text { Sinha et al } \\
(2018)^{24}\end{array}$ & 24-43 years old & Breast Cancer & Chemotherapy & $\begin{array}{l}\text { Taxotere } \\
\text { Cyclophosphamide } \\
\text { Carboplatin } \\
\text { Fluorouracil } \\
\text { Epirubicin }\end{array}$ & $\downarrow$ AFC & 88 \\
\hline $\begin{array}{l}\text { Al-Rawi et al } \\
(2018)^{25}\end{array}$ & $25-45$ years old & Breast Cancer & Chemotherapy & $\begin{array}{l}\text { Anthracycline } \\
\text { Cyclophosphamide }\end{array}$ & $\begin{array}{l}\downarrow \mathrm{AMH} \\
\downarrow \mathrm{E}_{2} \\
\uparrow \mathrm{LH}\end{array}$ & 58 \\
\hline $\begin{array}{l}\text { Anderson et al } \\
(2018)^{26}\end{array}$ & $18-45$ years old & Hodgkin Lymphoma & Chemotherapy & - & $\begin{array}{l}\downarrow \mathrm{AMH} \\
\downarrow \mathrm{E}_{2} \\
\uparrow \mathrm{FSH}\end{array}$ & 67 \\
\hline $\begin{array}{l}\text { D'Avila et al } \\
(2017)^{27}\end{array}$ & $27-40$ years old & Breast Cancer & Chemotherapy & Cyclophosphamide & $\begin{array}{l}\uparrow \text { Amenorrhea } \\
\uparrow \mathrm{FSH} \\
\downarrow \mathrm{AMH} \\
\downarrow \mathrm{AFC} \\
\uparrow \mathrm{E}_{2}\end{array}$ & 49 \\
\hline $\begin{array}{l}\text { Chang et al } \\
(2017)^{28}\end{array}$ & $15-51$ years old & $\begin{array}{l}\text { Chronic Myeloid } \\
\text { Leukemia }\end{array}$ & Chemotherapy & Imatinib & $\begin{array}{l}\downarrow \text { ejaculated volume } \\
\downarrow \text { Sperm } \\
\downarrow \text { seminal density } \\
\downarrow \text { Viability Sperm }\end{array}$ & 48 \\
\hline
\end{tabular}


Table 1 (Continued)

\begin{tabular}{|c|c|c|c|c|c|c|}
\hline Author & Age & Tumor type & Treatment & $\begin{array}{l}\text { Antineoplastic } \\
\text { agent }\end{array}$ & Effect & $\begin{array}{l}\text { Number } \\
\text { of patients }\end{array}$ \\
\hline $\begin{array}{l}\text { Creux et al } \\
(2017)^{29}\end{array}$ & $16-40$ years old & $\begin{array}{l}\text { Breast Cancer } \\
\text { Cervical Cancer } \\
\text { Hematological Cancer } \\
\text { Gynecological Cancer } \\
\text { Sarcoma } \\
\text { Gastrointestinal Cancer }\end{array}$ & Chemotherapy & - & IVM - (normality) & 164 \\
\hline $\begin{array}{l}\text { Wenners et al } \\
(2017)^{30}\end{array}$ & 28-46 years old & Breast Cancer & Chemotherapy & $\begin{array}{l}\text { Docetaxel } \\
\text { Doxorubicin } \\
\text { Fluorouracil } \\
\text { Cyclophosphamide } \\
\text { Epirubicin } \\
\text { Paclitaxel } \\
\text { Anthracycline }\end{array}$ & $\begin{array}{l}\downarrow \mathrm{ACF} \\
\downarrow \mathrm{AMH} \\
\uparrow \mathrm{FSH} \\
\uparrow \mathrm{LH}\end{array}$ & 51 \\
\hline $\begin{array}{l}\text { Perdrix et al } \\
(2017)^{31}\end{array}$ & 11-35 years old & Breast Cancer & $\begin{array}{l}\text { Chemotherapy } \\
+ \\
\text { Radiotherapy }\end{array}$ & $\begin{array}{l}\text { Fluorouracil } \\
\text { Epirubicin } \\
\text { Cyclophosphamide } \\
\text { Docetaxel }\end{array}$ & $\downarrow \mathrm{AMH}$ & 5775 \\
\hline $\begin{array}{l}\text { McLaughlin } \\
\text { et al }(2017)^{32}\end{array}$ & $12-30$ years old & Hodgkin Lymphoma & Chemotherapy & $\begin{array}{l}\text { Adriamicina } \\
\text { Bleomycin } \\
\text { Vinblastine } \\
\text { Dacarbazine } \\
\text { Vincristine } \\
\text { Etoposide } \\
\text { Prednisone } \\
\text { Doxorubicin } \\
\text { Cyclophosphamide }\end{array}$ & $\begin{array}{l}\downarrow \text { Follicular density } \\
\downarrow \text { Follicular development }\end{array}$ & 13 \\
\hline Abir et al $(2016)^{33}$ & $5-18$ years old & $\begin{array}{l}\text { Medulloblastoma } \\
\text { Acute Myeloid } \\
\text { Leukemia } \\
\text { Rhabdomyosarcoma } \\
\text { Ewing Sarcoma } \\
\text { Hodgkin Lymphoma } \\
\text { Osteosarcoma }\end{array}$ & Chemotherapy & - & $\begin{array}{l}\uparrow \text { Number of atretic follicles } \\
\downarrow \text { Oocyte maturation }\end{array}$ & 20 \\
\hline Hamy et al (2016) 34 & $26-43$ years old & Breast Cancer & Chemotherapy & - & $\downarrow \mathrm{AMH}$ & 134 \\
\hline Paoli et al $(2016)^{35}$ & $13-51$ years old & Hodgkin Lymphoma & Chemotherapy & $\begin{array}{l}\text { Doxorubicin } \\
\text { Bleomycin } \\
\text { Vinblastine } \\
\text { Dacarbazine }\end{array}$ & $\begin{array}{l}\downarrow \text { Sperm } \\
\uparrow \text { Sperm anomalies }\end{array}$ & 810 \\
\hline $\begin{array}{l}\text { Even-Or } \\
\text { et al }(2016)^{36}\end{array}$ & $13-36$ years old & $\begin{array}{l}\text { Acute Myeloid } \\
\text { Leukemia }\end{array}$ & Chemotherapy & Melfalano & $\begin{array}{l}\downarrow \mathrm{AMH} \\
\downarrow \mathrm{LH} \\
\downarrow \mathrm{FSH}\end{array}$ & 35 \\
\hline $\begin{array}{l}\text { Jacobson et al } \\
(2016)^{37}\end{array}$ & 20-35 years old & $\begin{array}{l}\text { Breast Cancer } \\
\text { Acute Myeloid Leukemia } \\
\text { Non Hodgkin Lymphoma }\end{array}$ & $\begin{array}{l}\text { Chemotherapy } \\
+ \\
\text { Radiotherapy }\end{array}$ & - & $\uparrow$ Amenorrhea & 1282 \\
\hline $\begin{array}{l}\text { Gupta et al } \\
(2016)^{38}\end{array}$ & $11-18$ years old & $\begin{array}{l}\text { Osteosarcoma } \\
\text { Hodgkin Lymphoma } \\
\text { B cell Lymphoma } \\
\text { Dysgerminoma } \\
\text { Osteosarcoma }\end{array}$ & Chemotherapy & $\begin{array}{l}\text { Cyclophosphamide } \\
\text { Doxorubicin } \\
\text { Cisplatine }\end{array}$ & $\downarrow \mathrm{AMH}$ & 17 \\
\hline $\begin{array}{l}\text { Ruddy et al } \\
(2015)^{39}\end{array}$ & 40-45 years old & Breast Cancer & Chemotherapy & $\begin{array}{l}\text { Trastuzumab } \\
\text { Paclitaxel }\end{array}$ & $\uparrow$ Amenorrhea & 410 \\
\hline $\begin{array}{l}\text { Huser et al } \\
(2015)^{40}\end{array}$ & $18-40$ years old & Hodgkin Lymphoma & Chemotherapy & $\begin{array}{l}\text { Adriamycin } \\
\text { Bleomycin } \\
\text { Vinblastine } \\
\text { Vincristine } \\
\text { Procarbazine } \\
\text { Prednisone } \\
\text { Etoposide } \\
\text { Doxorubicin } \\
\text { Cyclophosphamide }\end{array}$ & $\uparrow \mathrm{FSH}$ & 108 \\
\hline $\begin{array}{l}\text { Levi et al } \\
(2015)^{41}\end{array}$ & 20-44 years old & $\begin{array}{l}\text { Colon Cancer } \\
\text { Esophageal Cancer } \\
\text { Thymic Cancer } \\
\text { Rectal Cancer } \\
\text { Neck Cancer }\end{array}$ & Chemotherapy & $\begin{array}{l}\text { Cisplatine } \\
\text { Capecitabine } \\
\text { Fluoropyrimidine }\end{array}$ & $\begin{array}{l}\uparrow \mathrm{FSH} \\
\downarrow \text { Inhibin B } \\
\uparrow \mathrm{AMH}\end{array}$ & 20 \\
\hline $\begin{array}{l}\text { Thomas-Teinturier } \\
\text { et al }(2015)^{42}\end{array}$ & 18-39 years old & $\begin{array}{l}\text { Bone Sarcoma } \\
\text { Soft Tissue Sarcoma } \\
\text { Neuroblastoma }\end{array}$ & $\begin{array}{l}\text { Chemotherapy } \\
+ \\
\text { Radiotherapy }\end{array}$ & $\begin{array}{l}\text { Cyclophosphamide } \\
\text { Ifosfamide }\end{array}$ & $\begin{array}{l}\uparrow \mathrm{FSH} \\
\downarrow \mathrm{AMH}\end{array}$ & 105 \\
\hline
\end{tabular}


764 Cytotoxic Activity of Antineoplastic Agents on Fertility Moura, Monteiro

Table 1 (Continued)

\begin{tabular}{|c|c|c|c|c|c|c|}
\hline Author & Age & Tumor type & Treatment & $\begin{array}{l}\text { Antineoplastic } \\
\text { agent }\end{array}$ & Effect & $\begin{array}{l}\text { Number } \\
\text { of patients }\end{array}$ \\
\hline & & $\begin{array}{l}\text { Hodgkin Lymphoma } \\
\text { Non Hodgkin Lymphoma } \\
\text { Acute Lymphoid Leukemia }\end{array}$ & & $\begin{array}{l}\text { Procarbazine } \\
\text { busulfan }\end{array}$ & & \\
\hline $\begin{array}{l}\text { Meissner et al } \\
(2015)^{43}\end{array}$ & $18-40$ years old & Non Hodgkin Lymphoma & Chemotherapy & $\begin{array}{l}\text { Cyclophosphamide } \\
\text { Doxorubicin } \\
\text { Vincristine } \\
\text { Prednisone }\end{array}$ & $\begin{array}{l}\uparrow \text { Amenorrhea } \\
\downarrow \mathrm{AMH}\end{array}$ & 46 \\
\hline
\end{tabular}

Abbreviations: AFC, antral follicle count; AMH, anti-mullerian hormone; $E_{2}$, estradiol; FSH, follicle stimulating hormone; IVM, in vitro maturation; LH, luteinizing hormone.

Through our review, we can see that the production of the germ cells like oocytes and sperm has been altered. In two studies performed in patients undergoing treatment with male AQA, a reduction in the concentrate of sperm in the ejaculation was identified, as well as a reduction in the ejaculation and in the sperm survival, in addition to verifying the appearance of anomalies in its forms. 28,35
In seven clinical trials performed on female patients, there was a reduction in AFC and an increase in amenorrhea in the patients. ${ }^{22,24,27,30,36,39,43}$ In vitro assays were also considered for the analysis of the effects of AQA on female fertility; in two studies, there was an increase in follicular density in addition to presenting a greater amount of atretic follicle. ${ }^{32,33}$ The results are available in $\boldsymbol{- T a b l e} \mathbf{1}$.

Table 2 Influence of radiotherapy + antineoplastic chemotherapy agents on fertility pattern

\begin{tabular}{|c|c|c|c|c|c|c|c|}
\hline Author & Age & Tumor type & Treatment & Corporal site & Dosage & Effect & $\begin{array}{l}\text { Number of } \\
\text { patients }\end{array}$ \\
\hline $\begin{array}{l}\text { Duhil de Bénazé } \\
\text { et al }(2018)^{44}\end{array}$ & $7-18$ years old & Dysgerminoma & $\begin{array}{l}\text { Chemotherapy } \\
+ \\
\text { Radiotherapy }\end{array}$ & Lymphatic chains & $20 \mathrm{~Gy}$ & $\uparrow \mathrm{HcG}$ & 48 \\
\hline $\begin{array}{l}\text { Fernandez-Pineda } \\
\text { et al }(2018)^{45}\end{array}$ & 4-22 years old & Hodgkin Lymphoma & $\begin{array}{l}\text { Chemotherapy } \\
+ \\
\text { Radiotherapy }\end{array}$ & Pelvic & 9-55 Gy & $\uparrow \mathrm{POF}$ & 127 \\
\hline $\begin{array}{l}\text { Rives et al } \\
(2017)^{46}\end{array}$ & 24-43 years old & Testicular Cancer & $\begin{array}{l}\text { Chemotherapy } \\
+ \\
\text { Radiotherapy }\end{array}$ & Lymphatic chains & 25 Gy & $\begin{array}{l}\downarrow \text { Sperm } \\
\downarrow \text { Sperm motility }\end{array}$ & 54 \\
\hline $\begin{array}{l}\text { Green et al } \\
(2017)^{47}\end{array}$ & $0-15$ years old & $\begin{array}{l}\text { Acute Lymphoid } \\
\text { Leukemia }\end{array}$ & $\begin{array}{l}\text { Chemotherapy } \\
+ \\
\text { Radiotherapy }\end{array}$ & $\begin{array}{l}\text { Testicular } \\
\text { Hypothalamic } \\
\text { Pituitary }\end{array}$ & $>40 \mathrm{~Gy}$ & $\begin{array}{l}\downarrow \text { Sperm } \\
\downarrow \text { Sperm motility } \\
\downarrow \text { LH } \\
\downarrow \text { FSH }\end{array}$ & 171 \\
\hline $\begin{array}{l}\text { Chemaitilly et al } \\
(2017)^{48}\end{array}$ & $18-45$ years old & $\begin{array}{l}\text { Leukemia } \\
\text { Lymphoma } \\
\text { Central Nervous } \\
\text { System Tumors } \\
\text { Embryonic Tumors } \\
\text { Bone Tissue Sarcoma } \\
\text { Carcinomas }\end{array}$ & $\begin{array}{l}\text { Chemotherapy } \\
+ \\
\text { Radiotherapy }\end{array}$ & $\begin{array}{l}\text { Pelvic } \\
\text { Lumbar region } \\
\text { Sacral } \\
\text { Entire Spine } \\
\text { Abdominal flank } \\
\text { Para-aortic } \\
\text { Iliac } \\
\text { Bladder } \\
\text { Vaginal } \\
\text { Lymphoid }\end{array}$ & $>30 \mathrm{~Gy}$ & $\uparrow \mathrm{POF}$ & 988 \\
\hline $\begin{array}{l}\text { Chow et al } \\
(2016)^{49}\end{array}$ & $5-20$ years old & $\begin{array}{l}\text { Leukemia } \\
\text { Central Nervous } \\
\text { System Tumors } \\
\text { Lymphoma } \\
\text { Renal tumor } \\
\text { Neuroblastoma } \\
\text { Soft Tissue Tumor } \\
\text { Bone tumor }\end{array}$ & $\begin{array}{l}\text { Chemotherapy } \\
+ \\
\text { Radiotherapy }\end{array}$ & $\begin{array}{l}\text { Neck } \\
\text { Chest } \\
\text { Legs } \\
\text { Arms }\end{array}$ & - & $\uparrow$ Sterility rate & 10938 \\
\hline $\begin{array}{l}\text { Boltežar et al } \\
(2016)^{50}\end{array}$ & $18-40$ years old & Hodgkin Lymphoma & $\begin{array}{l}\text { Chemotherapy } \\
+ \\
\text { Radiotherapy }\end{array}$ & Pelvic & 24 Gy & $\uparrow$ Amenorrhea & 131 \\
\hline $\begin{array}{l}\text { Sonigo et al } \\
(2016)^{51}\end{array}$ & 17-33 years old & $\begin{array}{l}\text { Hodgkin Lymphoma } \\
\text { Breast Cancer }\end{array}$ & $\begin{array}{l}\text { Chemotherapy } \\
+ \\
\text { Radiotherapy }\end{array}$ & Subdiaphragmatic & $>26$ Gy & $\downarrow$ IVM & 22 \\
\hline
\end{tabular}

Abbreviations: FSH, follicle atimulating hormone; HcG, human chorionic gonadotropin; IVM, in vitro maturation; LH, luteinizing hormone; POF, premature ovarian failure. 


\section{Radiotherapy Combined with Chemotherapy can Modulate Serum Hormonal Secretion and Alter the Production of Germ Cells, in Addition to Directly Interfering with Their Depletion}

During the present review, two studies performed on patients undergoing chemotherapy regimens combined with radiation therapy at dosages $<40 \mathrm{~Gy}$ in the lymph node region led to a serum reduction of the hormones FSH and $\mathrm{LH}$ in male patients and of the chorionic gonadotropin (Hcg) hormone in female patients. Two authors showed a significant reduction in sperm concentration and progressive motility in male patients. A single study performed in vitro showed that with the administration of chemotherapy in combination with radiotherapy in the subdiaphragmatic region with a dosage of $20 \mathrm{~Gy}$ led to a reduction in the success rates of oocytes In Vitro Maturation (IVM) in these patients. Two studies also showed the ability that combination of antineoplastic treatments in concentrations ranging from 20 to $30 \mathrm{~Gy}$ had in depleting the ovarian content leading to premature ovarian failure (POF) syndrome, receiving radiation in the pelvic, sacral, and lumbar region, in the entire spine, in the flank of the abdomen, in the inverted $Y$ region, in the para-aortic, in the iliac region, in the bladder region, in the vaginal and in the lymphoid region. In another cohort study performed with patients of both genders undergoing chemotherapy plus radiotherapy, there was the possibility of an increase in sterility rates in the patients. ${ }^{44-51}$ The results are available in - Table 2 .

\section{Discussion}

The increase in the number of more aggressive antineoplastic treatments can lead to improvements in the survival rate of young patients diagnosed with CA. ${ }^{52}$ However, these therapies can also cause infertility and sterility, where providers and patients tolerate these adverse effects with the ideal of survival being the sole objective. ${ }^{53}$ With the development of current assisted reproduction technologies and hormonal restoration procedures, including in vitro fertilization and ovarian transplantation, the possibilities for preserving the fertility of the patients have been increased; however, they do not provide long-term solutions and leave pediatric patients with metastatic tumors without options. ${ }^{54}$

Currently, among the main types of treatment, are traditional chemotherapy and radiotherapy, which may be correlated in the short and long terms with effects on fertility that end up aggravating the suffering of patients during treatment. ${ }^{6}$ It is important to note that for men and women of childbearing age, concerns about loss of fertility may end up influencing the choice of adherence to treatment regimens. ${ }^{55}$ Thus, the systematic resolution of adverse effects that may occur during treatment becomes something necessary and, being aware of the antineoplastic pharmacological cytotoxicity, it is possible to improve decision-making regarding treatment adherence. ${ }^{56}$

In the present review, it was possible to observe a serum hormonal modulation with the use of AQA. Such results have also been presented in the literature, as in the study by Huddart et $\mathrm{al}^{57}$ who observed that 367 patients exposed to therapies with AQA had increased levels of LH and FSH. These results were found again in the study by Madhu et al in $2016,{ }^{58}$ who found an increase in LH and FSH levels and a decrease in testosterone after an initial treatment period with AQA. This is mainly due to hormonal feedback driven by the hypothalamic-pituitary gonadal axis in which the synthesis of these sex steroids will control the production of mature gametes present during therapy and will trigger an increase in their concentrations. ${ }^{59,60}$

In our review, we can see that mainly AMH was modulated. These results are present in the literature, as previously observed by Levi et al, ${ }^{41}$ who in studies with mice mimicking chemotherapy antineoplastic treatment found that there was a reduction in AMH in 19 mice. Such modification is due to the reduction in the amount of antral follicles present in the ovarian reserve in women and the reduction of male sexual gametes, which due to the fact that $\mathrm{AMH}$ is a glycoprotein present in the germinal tissues that end up producing these hormones ends up having the levels negatively modulated until complete recovery and therapy is stopped, and can be considered a good marker of ovarian reserve for patients undergoing CA treatment. ${ }^{61}$

Another important factor observed in the present review was an increase in atretic follicles, reduction in Antral Follicle Count (AFC) in female patients, effects also observed in the concentration of sperm and changes in seminal parameters of patients exposed to AQA. The literature infers this activity of AQA to a nonspecificity of these agents, in which drugs that must attack cells with a marked proliferative phenotypic profile start to attack cells of similar profile leading to adverse effects. ${ }^{62}$ Such activity will lead to the attack of somatic and granula cells, interfering directly in folliculogenesis, leading to poor follicular development both in vivo and in vitro. ${ }^{63}$

The current consensus for treatments of some types of localized CA involves the provision of AR regardless of the use of chemotherapy. ${ }^{64}$ However, in the present review, no articles were found using radiotherapy alone as a treatment choice. We observed that in concentrations between $20 \mathrm{~Gy}$ to a range of $55 \mathrm{~Gy}$ in the different regions to which the ion beam is applied, they exercise activities modulating both the hormonal levels and leading to patient sterility. These results are similar to the study by Isaksson et al, ${ }^{65}$ who observed that radiotherapy located in testicular cancer led to modulation of sex hormones, including reduction of inhibin $B$.

During the present review, it was not possible to observe differences between effects from chemotherapy and radiotherapy in patients of different age groups, due to obtaining similar effects in the studies. What again comes into consensus with the literature according to a study by Paoli et al, ${ }^{66}$ it is observed that age is not considered a determining factor for the protection or decline of fertility, corroborating the hypothesis that the effects of antineoplastic therapies on fertility are dose dependent.

\section{Conclusion}

In conclusion, antineoplastic treatments have a potential cytotoxic effect on the fertility of patients undergoing CA 
treatment. The age at which the patient starts treatment does not show to be a protective factor or an accelerator of effects on fertility; however, the accumulated dosage in tissues has a fundamental impact on the fertility of these patients.

\section{Conflict of Interests}

The authors have no conflict of interests to declare.

\section{References}

1 Ramazzotti D, Lal A, Wang B, Batzoglou S, Sidow A. Multi-omic tumor data reveal diversity of molecular mechanisms that correlate with survival. Nat Commun. 2018;9(01):4453. Doi: 10.1038/ s41467-018-06921-8

2 Hanahan D, Weinberg RA. Hallmarks of cancer: the next generation. Cell. 2011;144(05):646-674. Doi: 10.1016/j.cell.2011.02.013

3 World Health Organization. Improving affordability and effectiveness of cancer medicines [Internet]. 2018 [cited 2018 Aug 13]. Available from: http://www.who.int/medicines/areas/access/Improving-affordability-effectiveness-of-cancer-medicines/en/

4 Duarte AF, Sousa-Pinto B, Haneke E, Correia O. Risk factors for development of new skin neoplasms in patients with past history of skin cancer: A survival analysis. Sci Rep. 2018;8(01):15744. Doi: 10.1038/s41598-018-33763-7

5 Tarín JJ, García-Pérez MA, Cano A. Obstetric and offspring risks of women's morbid conditions linked to prior anticancer treatments. Reprod Biol Endocrinol. 2016;14(01):37. Doi: 10.1186/s12958-0160169-6

6 Hassan I, Khan AA, Aman S, Qamar W, Ebaid H, Al-Tamimi J, et al Restrained management of copper level enhances the antineoplastic activity of imatinib in vitro and in vivo. Sci Rep. 2018;8 (01):1682. Doi: 10.1038/s41598-018-19410-1

7 Plummer C, Driessen C, Szabo Z, Mateos MV. Management of cardiovascular risk in patients with multiple myeloma. Blood Cancer J. 2019;9(03):26. Doi: 10.1038/s41408-019-0183-y

8 Cavaletti G, Marmiroli P. Chemotherapy-induced peripheral neurotoxicity. Curr Opin Neurol. 2015;28(05):500-507. Doi: 10.1097/WCO.0000000000000234

9 Matoso LML, Rosário SSD, Matoso MBL. As estratégias de cuidados para o alívio dos efeitos colaterais da quimioterapia em mulheres. Saúde (Santa Maria). 2015;41(02):251-260. Doi: 10.5902/ 2236583410883

10 Donnez J, Dolmans MM. Fertility preservation in women. Nat Rev Endocrinol. 2013;9(12):735-749. Doi: 10.1038/nrendo.2013.205

11 De Ruysscher D, Niedermann G, Burnet NG, Siva S, Lee AWM, Hegi-Johnson F. Radiotherapy toxicity. Nat Rev Dis Primers. 2019; 5(01):13. Doi: 10.1038/s41572-019-0064-5

12 Katz DJ, Kolon TF, Feldman DR, Mulhall JP. Fertility preservation strategies for male patients with cancer. Nat Rev Urol. 2013;10 (08):463-472. Doi: 10.1038/nrurol.2013.145

13 Bénard J, Duros S, El Hachem H, Sonigo C, Sifer C, Grynberg M. Freezing oocytes or embryos after controlled ovarian hyperstimulation in cancer patients: the state of the art. Future Oncol. 2016; 12(14):1731-1741. Doi: 10.2217/fon-2016-0095

14 MacLeod KJ, McCormick GL, Langkilde T. Glucocorticoids do not influence a secondary sexual trait or its behavioral expression in eastern fence lizards. Sci Rep. 2019;9(01):5229. Doi: 10.1038/ s41598-019-41596-1

15 Lenz KM, Pickett LA, Wright CL, Galan A, McCarthy MM. Prenatal allergen exposure perturbs sexual differentiation and programs lifelong changes in adult social and sexual behavior. Sci Rep. 2019; 9(01):4837. Doi: 10.1038/s41598-019-41258-2

16 Ramstein JJ, Halpern J, Gadzinski AJ, Brannigan RE, Smith JF. Ethical, moral, and theological insights into advances in male pediatric and adolescent fertility preservation. Andrology. 2017;5 (04):631-639. Doi: 10.1111/andr.12371
17 Hisasi CS, Cortez DEA, Pomin T, Felix JS, Mesquita SFP. Alterações testiculares em rato pré-púberes após tratamento subcrônico com doxorubicina. Bol Cent Biol Reprod. 2007;26 $(1 / 2): 66-70$

18 Veloso EVL, Figueirêdo LCM, Menezes DJA, Sousa OB, Santos JRS. Efeitos de sulfato de vincristine sobre os testículos de ratos albinos, tratados na fase pré-púbere. Pesqui Vet Bras. 2018;38 (06):1217-1224. Doi: 10.1590/1678-5150-pvb-4782

19 Cabral REL, Mendes TB, Vendramini V, Miraglia SM. Carnitine partially improves oxidative stress, acrosome integrity, and reproductive competence in doxorubicin-treated rats. Andrology. 2018;6(01):236-246. Doi: 10.1111/andr.12426

20 Pati D, Lorusso LN. How to write a systematic review of the literature. HERD. 2018;11(01):15-30. Doi: 10.1177/1937586717747384

21 PRISMA. PRISMA Statement [Internet]. 2009 [cited 2018 Aug 13]. Available from: http://www.prisma-statement.org/PRISMA Statement/

22 Gini G, Annibali O, Lupasco D, Bocci C, Tomarchio V, Sampaolo M, et al. Gonadal function recovery and fertility in women treated with chemo-and/or radiotherapy for Hodgkin's and non-Hodgkin lymphoma. Chemotherapy. 2019;64(01):36-41. Doi: 10.1159/000499535

23 Shandley LM, Fothergill A, Spencer JB, Mertens AC, Cottrell HN, Howards PP. Impact of cancer treatment on risk of infertility and diminished ovarian reserve in women with polycystic ovary syndrome. Fertil Steril. 2018;109(03):516-525.e1. Doi: 10.1016/j.fertnstert.2017.11.016

24 Sinha N, Letourneau JM, Wald K, Xiong P, Imbar T, Li B, et al. Antral follicle count recovery in women with menses after treatment with and without gonadotropin-releasing hormone agonist use during chemotherapy for breast cancer. J Assist Reprod Genet. 2018;35(10):1861-1868. Doi: 10.1007/s10815-018-1203-8

25 Al-Rawi SA, Saleh BO, Al-Naqqash MA. Serum anti-müllerian hormone levels in evaluation of chemotherapy effect on ovarian reserve in women with breast cancer. A follow-up study. Saudi Med J. 2018;39(07):733-735. Doi: 10.15537/smj.2018.7.21897

26 Anderson RA, Remedios R, Kirkwood AA, Patrick P, Stevens L, Clifton-Hadley L, et al. Determinants of ovarian function after response-adapted therapy in patients with advanced Hodgkin's lymphoma (RATHL): a secondary analysis of a randomised phase 3 trial. Lancet Oncol. 2018;19(10):1328-1337. Doi: 10.1016/ S1470-2045(18)30500-X

27 D'Avila AM, Capp E, Corleta HVE. Antral follicles count and antiMüllerian hormone levels after gonadotoxic chemotherapy in patients with breast cancer: cohort study. Rev Bras Ginecol Obstet. 2017;39(04):162-168. Doi: 10.1055/s-0037-1601438

28 Chang X, Zhou L, Chen X, Xu B, Cheng Y, Sun S, et al. Impact of imatinib on the fertility of male patients with chronic myelogenous leukaemia in the chronic phase. Target Oncol. 2017;12(06): 827-832. Doi: 10.1007/s11523-017-0521-6

29 Creux H, Monnier P, Son WY, Tulandi T, Buckett W. Immature oocyte retrieval and in vitro oocyte maturation at different phases of the menstrual cycle in women with cancer who require urgent gonadotoxic treatment. Fertil Steril. 2017;107(01):198-204. Doi: 10.1016/j.fertnstert.2016.09.041

30 Wenners A, Grambach J, Koss J, Maass N, Jonat W, Schmultzer A, Mundhenke $C$. Reduced ovarian reserve in young early breast cancer patients: preliminary data from a prospective cohort trial. BMC Cancer. 2017;17(01):632. Doi: 10.1186/s12885-017-3593-x

31 Perdrix A, Saint-Ghislain M, Degremont M, et al. Influence of adjuvant chemotherapy on anti-Müllerian hormone in women below 35 years treated for early breast cancer. Reprod Biomed Online. 2017;35(04):468-474. Doi: 10.1016/j.rbmo.2017.06.005

32 McLaughlin M, Kelsey TW, Wallace WH, Anderson RA, Telfer EE. Non-growing follicle density is increased following adriamycin, bleomycin, vinblastine and dacarbazine (ABVD) chemotherapy in the adult human ovary. Hum Reprod. 2017;32(01):165-174. Doi: 10.1093/humrep/dew260 
33 Abir R, Ben-Aharon I, Garor R, et al. Cryopreservation of in vitro matured oocytes in addition to ovarian tissue freezing for fertility preservation in paediatric female cancer patients before and after cancer therapy. Hum Reprod. 2016;31(04):750-762. Doi: 10.1093/humrep/dew007

34 Hamy AS, Porcher R, Eskenazi S, Cuvier C, Giacchetti S, Coussy F, et al. Anti-Müllerian hormone in breast cancer patients treated with chemotherapy: a retrospective evaluation of subsequent pregnancies. Reprod Biomed Online. 2016;32(03):299-307. Doi: 10.1016/j.rbmo.2015.12.008

35 Paoli D, Rizzo F, Fiore G, Pallotti F, Pulsoni A, Annechini G, et al. Spermatogenesis in Hodgkin's lymphoma patients: a retrospective study of semen quality before and after different chemotherapy regimens. Hum Reprod. 2016;31(02):263-272. Doi: 10.1093/ humrep/dev310

36 Even-Or E, Ben-Haroush A, Yahel A, Yaniv I, Stein J. Fertility after treatment with high dose melphalan in women with acute myelogenous leukemia. Pediatr Blood Cancer. 2016;63(02): 334-336. Doi: 10.1002/pbc.25765

37 Jacobson MH, Mertens AC, Spencer JB, Manatunga AK, Howards PP. Menses resumption after cancer treatment-induced amenorrhea occurs early or not at all. Fertil Steril. 2016;105(03):765-772. e4. Doi: $10.1016 /$ j.fertnstert.2015.11.020

38 Gupta AA, Lee Chong A, Deveault C, Traubici J, Maloney AM, Knight $S$, et al. Anti-Müllerian hormone in female adolescent cancer patients before, during, and after completion of therapy: a pilot feasibility study. J Pediatr Adolesc Gynecol. 2016;29(06): 599-603. Doi: 10.1016/j.jpag.2016.04.009

39 Ruddy KJ, Guo H, Barry W, Dang CT, Yardley DA, Moy B, et al. Chemotherapy-related amenorrhea after adjuvant paclitaxeltrastuzumab (APT trial). Breast Cancer Res Treat. 2015;151(03): 589-596. Doi: 10.1007/s10549-015-3426-z

40 Huser M, Smardova L, Janku P, Crha I, Zakova J, Stourac P, et al. Fertility status of Hodgkin lymphoma patients treated with chemotherapy and adjuvant gonadotropin-releasing hormone analogues. J Assist Reprod Genet. 2015;32(08):1187-1193. Doi: 10.1007/s10815-015-0452-z

41 Levi M, Hasky N, Stemmer SM, Shalgi R, Ben-Aharon I. AntiMüllerian hormone is a marker for chemotherapy-induced testicular toxicity. Endocrinology. 2015;156(10):3818-3827. Doi: 10.1210/en.2015-1310

42 Thomas-Teinturier C, Allodji RS, Svetlova E, Frey M-A, Obertlin O, Millischer A-E, et al. Ovarian reserve after treatment with alkylating agents during childhood. Hum Reprod. 2015;30(06): 1437-1446. Doi: 10.1093/humrep/dev060

43 Meissner J, Tichy D, Katzke V, Kuhn T, Dietrich S, Schmitt T, et al. Long-term ovarian function in women treated with $\mathrm{CHOP}$ or CHOP plus etoposide for aggressive lymphoma. Ann Oncol. 2015;26(08):1771-1776. Doi: 10.1093/annonc/mdv227

44 Duhil de Bénazé G, Pacquement H, Faure-Conter C, Patte C, Orbach D, Corradini N, et al. Paediatric dysgerminoma: Results of three consecutive French germ cell tumours clinical studies (TGM85/90/95) with late effects study. Eur J Cancer. 2018;91:30-37. Doi: 10.1016/j.ejca.2017.11.030

45 Fernandez-Pineda I, Davidoff AM, Lu L, Rao BN, Wilson CL, Srivastava DK, et al. Impact of ovarian transposition before pelvic irradiation on ovarian function among long-term survivors of childhood Hodgkin lymphoma: A report from the St. Jude Lifetime Cohort Study. Pediatr Blood Cancer. 2018;65(09):e27232. Doi: 10.1002/pbc.27232

46 Rives N, Walschaerts M, Setif V, Hennebicq S, Saias J, Brugnon F, et al. Sperm aneuploidy after testicular cancer treatment: data from a prospective multicenter study performed within the French Centre d'Étude et de Conservation des Oeufs et du Sperme network. Fertil Steril. 2017;107(03):580-588.e1. Doi: 10.1016/j. fertnstert.2016.11.015

47 Green DM, Zhu L, Wang M, Chemaitilly W, Srivastava D, Kutteh $\mathrm{WH}$, et al. Effect of cranial irradiation on sperm concentration of adult survivors of childhood acute lymphoblastic leukemia: a report from the St. Jude Lifetime Cohort Study. Hum Reprod. 2017;32(06):1192-1201. Doi: 10.1093/humrep/dex082

48 Chemaitilly W, Li Z, Krasin MJ, et al. Premature ovarian insufficiency in childhood cancer survivors: a report from the St. Jude Lifetime Cohort. J Clin Endocrinol Metab. 2017;102(07):2242-2250. Doi: 10.1210/jc.2016-3723

49 Chow EJ, Stratton KL, Leisenring WM, Oeffinger KC, Sklar CA, Donaldson SS, et al. Pregnancy after chemotherapy in male and female survivors of childhood cancer treated between 1970 and 1999: a report from the Childhood Cancer Survivor Study cohort. Lancet Oncol. 2016;17(05):567-576. Doi: 10.1016/S1470-2045(16)00086-3

50 Boltežar L, Pintarić K, Jezeršek Novaković B. Fertility in young patients following treatment for Hodgkin's lymphoma: a single center survey. J Assist Reprod Genet. 2016;33(03):325-333. Doi: 10.1007/s10815-015-0636-6

51 Sonigo C, Seroka A, Cédrin-Durnerin I, Sermondade N, Sifer C, Grynberg M. History of ABVD alters the number of oocytes vitrified after in vitro maturation in fertility preservation candidates. Future Oncol. 2016;12(14):1713-1719. Doi: 10.2217/fon-2016-0009

52 Xiao S, Zhang J, Romero MM, Smith KN, Shea LD, Woodruff TK. In vitro follicle growth supports human oocyte meiotic maturation. Sci Rep. 2015;5:17323. Doi: 10.1038/srep17323

53 Woodruff TK. The Oncofertility Consortium-addressing fertility in young people with cancer. Nat Rev Clin Oncol. 2010;7(08): 466-475. Doi: 10.1038/nrclinonc.2010.81

54 Laronda MM, Rutz AL, Xiao S, Whelan KA, Duncan FE, Roth EW, et al. A bioprosthetic ovary created using 3D printed microporous scaffolds restores ovarian function in sterilized mice. Nat Commun. 2017;8:15261. Doi: 10.1038/ncomms15261

55 Xu M, Pavone ME, Woodruff T. Fruitful progress to fertility: preserving oocytes from chemodestruction. Nat Med. 2011;17 (12):1562-1563. Doi: 10.1038/nm.2595

56 Carvalho B, Caetano J, Cavagna M, Marinho M, Silva A, Nakagawa M. Indução de ovulação em pacientes com tumor estrogêniodependente: diretrizes clínicas da Sociedade Brasileira de Reprodução Humana. Reprod Clim. 2017;32(01):31-38. Doi: 10.1016/j. recli.2016.02.001

57 Huddart RA, Norman A, Moynihan C, Horwich A, Parker C, Nicholls E, Dearnaley DP. Fertility, gonadal and sexual function in survivors of testicular cancer. Br J Cancer. 2005;93(02): 200-207. Doi: 10.1038/sj.bjc.6602677

58 Madhu P, Reddy KP, Reddy PS. Role of melatonin in mitigating chemotherapy-induced testicular dysfunction in Wistar rats. Drug Chem Toxicol. 2016;39(02):137-146. Doi: 10.3109/ 01480545.2015.1055359

59 Liang S, Kinghorn AB, Voliotis M, Prague JK, Veldhuis JD, Tsaneva-Atanasova $\mathrm{K}$, et al. Measuring luteinising hormone pulsatility with a robotic aptamer-enabled electrochemical reader. Nat Commun. 2019;10(01):852. Doi: 10.1038/s41467019-08799-6

60 Chang ZL, Li BX, Liu B, Yao Lu, Yu, Jie, Jiang GM, Tan J-H. Effects of FSH and the weather during induced ovulation and timed artificial insemination to increase jenny conception rates. Sci Rep. 2019;9(01):3220. Doi: 10.1038/s41598-019-39757-3

61 Pergialiotis V, Koutaki D, Christopoulos-Timogiannakis E, Kotrogianni P, Perrea DN, Daskalakis G. Anti-Müllerian Hormone Levels in Preeclampsia: A Systematic Review of the Literature. J Family Reprod Health. 2017;11(04):179-184

62 Brandão HN, David JP, Couto RD, Nascimento JAP, David JM. Química e farmacologia de quimioterápicos antineoplásicos derivados de plantas. Quim Nova. 2010;33(06):1359-1369. Doi: 10.1590/S0100-40422010000600026

63 Martinez RM, Hauser R, Liang L, Mansur A, Adir M, Dioni L, et al. Urinary concentrations of phenols and phthalate metabolites reflect extracellular vesicle microRNA expression in follicular fluid. Environ Int. 2019;123:20-28. Doi: 10.1016/j. envint.2018.11.043 
64 Park J, Park Y, Lee SU, Kim T, Choi YK, Kim JY. Differential dosimetric benefit of proton beam therapy over intensity modulated radiotherapy for a variety of targets in patients with intracranial germ cell tumors. Radiat Oncol. 2015;10:135. Doi: 10.1186/s13014-015-0441-5

65 Isaksson S, Eberhard J, Ståhl O, Cavallin-Ståhl E, Cohn-Cedermark $\mathrm{G}$, Arver $\mathrm{S}$, et al. Inhibin $\mathrm{B}$ concentration is predictive for long- term azoospermia in men treated for testicular cancer. Andrology. 2014;2(02):252-258. Doi: 10.1111/j.2047-2927.2014. 00182.x

66 Paoli D, Gallo M, Rizzo F, et al. Testicular cancer and sperm DNA damage: short- and long-term effects of antineoplastic treatment. Andrology. 2015;3(01):122-128. Doi: 10.1111/j.20472927.2014.00250.x 